\title{
An INTERNATIONAL CASE FOR THE United STATES AdOPTING A QUALIFIEd PRIVILEGE FOR
}

\section{SOURCE CONFIDENTIALITY}

\author{
Bennett D. Fuson*
}

\section{INTRODUCTION}

In 2006, James Risen, a Pulitzer Prize winning reporter for The New York Times, released a book entitled "State of War." In the book, Risen described "a botched C.I.A. operation in which the agency provided flawed schematics to Iran in hopes of delaying its nuclear program." ${ }^{2}$ Risen further suggested that the Iranians noticed the flaw and could have disregarded it. ${ }^{3}$ In 2008 , after the book's release, the Justice Department (during then President George W. Bush's administration) sought to compel Risen to testify as a witness about his knowledge and, more specifically, his source of information in a case against former C.I.A. officer Jeffrey Sterling, who the Justice Department believed disclosed the confidential information regarding Iran to Risen for his book. ${ }^{4}$

Risen refused to testify pursuant to the 2008 subpoena; the Justice Department, now under the Obama administration's orders, again subpoenaed Risen in $2011 .{ }^{5}$ Risen challenged the second subpoena's demands all the way to the Supreme Court, where in 2014 the Court refused to hear Risen's appeal of a judgment from the U.S. Court of Appeals for the Fourth Circuit compelling

\footnotetext{
* J.D. Candidate, Indiana University Robert H. McKinney School of Law

${ }^{1}$ Adam Liptak, Supreme Court Rejects Appeal From Times Reporter Over Refusal to Identify Source, THE NEW YORK TIMES (June 2, 2014), http://www.nytimes.com/2014/06/03/us/james-risen-faces-jail-time-for-refusing-to-identify-aconfidential-source.html [http://perma.cc/Z26R-EQ7Q].

${ }^{2}$ Matt Apuzzo, Defiant on Witness Stand, Times Reporter Says Little, The New York Times (Jan. 5, 2015), http://www.nytimes.com/2015/01/06/us/james-risen-in-tense-testimony-refuses-to-offer-clues-on-sources.html [http://perma.cc/W6QX-GUTV].

${ }^{3} \mathrm{Id}$.

${ }^{4} I d$.

${ }^{5} \mathrm{Id}$.
} 
the journalist to testify. ${ }^{6}$ Ordered before federal prosecutors, Risen maintained his refusal to disclose his source, instead stating, "I am not going to provide the government with information that they seem to want to use to create a mosaic to prove or disprove certain facts...."

If this sounds like a familiar tale - reporter gets confidential information, federal government pursues reporter for disclosure, reporter refuses to disclose - perhaps it is because it is, in fact, part of a vicious, repeating cycle. From this ordeal, Risen finds himself in, if not good, then indeed bountiful company, joining the likes of Judith Miller, ${ }^{8}$ Josh Wolf, ${ }^{9}$ Jim Taricani, ${ }^{10}$ and Vanessa Leggett ${ }^{11}$ - all journalists who were incarcerated in some capacity for refusing to provide confidential information or disclose their source's identity. Risen, however, was more fortunate than his peers; Attorney General Eric Holder prohibited federal prosecutors from pressing Risen to reveal his sources after Risen took the stand, and the Justice Department subsequently dropped the subpoena. ${ }^{12}$

For a nation that prides itself on constitutional protections granting a free press, the United States has engaged in a troubling and systematic pursuit of confidential information (and, more specifically, confidential sources) gathered by reporters in an effort to pursue leaked information. Despite Attorney General Holder's restraint on compelling Risen to disclose his confidential source, the Justice Department under the Obama administration has brought more charges for

\footnotetext{
${ }^{6}$ Liptak, supra note 1.

${ }^{7}$ Apuzzo, supra note 2.

${ }^{8}$ See Sandra Davidson and David Herrera, Needed: More Than a Paper Shield, 20 WM. \& MARY BILL OF RTS. J. 1277 (2012) (discussing Miller's refusal to reveal her source regarding the disclosure of C.I.A. operative Valerie Plame's true identity).

${ }^{9} I d$. at 1285 (discussing Wolf's incarceration for refusing to surrender raw video footage of a G-8 Summit protest).

${ }^{10} I d$. at 1286 (discussing Taricani's house arrest for refusing to reveal his source for an FBI videotape showing a Providence, RI public official's acceptance of a bribe from an undercover FBI agent).

${ }^{11} I d$. at 1288 (discussing Leggett's incarceration for refusing to surrender notes and tapes of interviews she made during an investigation of a murder).

${ }^{12}$ Matt Apuzzo, Times Reporter Will Not Be Called to Testify in Leak Case, THE New York Times (Jan. 12, 2015), http://www.nytimes.com/2015/01/13/us/times-reporter-james-risen-will-not-be-called-to-testify-in-leak-caselawyers-say.html [http://perma.cc/K5KE-69WU].
} 
instances of leaking information than all previous administrations combined. ${ }^{13}$ Indeed, the Obama administration argued in its case against Risen that "reporters have no privilege to refuse to provide direct evidence of criminal wrongdoing by confidential sources." ${ }^{\prime 14}$ This is largely a problem for journalists facing a subpoena from federal court; virtually all states have extended at least partial protections to journalists from requiring disclosure of their confidential sources. ${ }^{15}$

On this matter the United States stands largely alone, particularly among countries acknowledged for their democratic governance. The European Union has recognized that a qualified reporter's privilege - that is, a privilege to maintain source confidentiality that can be overruled under certain conditions - exists for citizens of its participating nations. More recently, Canada's high court established circumstances under which a qualified reporter's privilege could be found to exist. And, the Organization of American States, an organization to which the United States is a member (and whose headquarters it hosts in Washington, DC) has declared that such protections exist, not only for journalists but for all "social commentators." Yet the United States has continued its refusal, by both Congressional inaction and lack of Supreme Court judicial review, to recognize such a protection as available to its citizens in federal matters.

That the United States chooses to hold onto a position of denying what its peers have determined to be a fundamental right is beyond reproach. As such, this Note argues that, to align itself with its international peers and set an example for the other American nations, the United States should ratify the Inter-American Declaration of Principles on Human Rights to establish a qualified privilege for source confidentiality.

\footnotetext{
${ }^{13}$ Apuzzo, supra note 12.

${ }^{14}$ Liptak, supra note 1.

${ }^{15}$ Christine Tatum, Federal Shield Would Protect Public's Right to Know, SocIETY OF ProfeSSIONAL JOURNALISTS, http://www.spj.org/rrr.asp?ref=58\&t=foia [http://perma.cc/S9MT-3S9E].
} 
Part II of this Note will briefly discuss the concept of a reporter's "privilege" to maintain source confidentiality, as well as the difference between an "absolute privilege" (a level of protection that a number of states have extended to journalists) and "qualified privilege," which, embracing the reality of contemporary American politics as well as a similar standard applied in both Canada and the European Union, this Note advocates as preferential. Part III of this Note will briefly discuss the United States' history of requiring disclosure of confidential sources, beginning with the Supreme Court's ruling in Branzburg v. Hayes, followed by a brief overview of subsequent federal case law dealing with reporter's privilege, as well as Congressional attempts to pass a federal "shield law." Part IV will introduce the Organization of American States (of which the United States is a member) and the Inter-American Declaration of Principles on Freedom of Expression, which this Note will argue is the template for qualified privilege that the United States should adopt. Part V will discuss the qualified privilege granted in both Canada and the European Union as an example of balancing reporters' rights to maintain confidentiality against concerns of national security. Part VI will briefly describe the benefits of ratifying the Inter-American Declaration of Principles on Freedom of Communication rather than enacting (or rather, as recent history demonstrates, failing to enact) federal legislation. Part VII will conclude with a summary of this Note's arguments determining that it is in the United States' best interest to ratify and adopt the provisions of the Inter-American Declaration of Principles on Freedom of Communication to provide journalists with a federal protection of source confidentiality.

\section{UNDERSTANDING “PRIVILEGE” AND ITS SCOPE}


To adequately present an argument that the United States should embrace a federal reporter's privilege, one must first determine what exactly a reporter's privilege entails. A reporter's privilege is, at its most basic level, analogous to the attorney-client privilege: a source contacts a journalist to disclose certain information, some of which may be confidential, and may sometimes request that his or her identity be kept confidential to avoid any associated repercussions stemming from the disclosure. ${ }^{16}$ Journalists frequently use confidential sources; ${ }^{17}$ while the Washington Post's coverage of the Watergate scandal most frequently comes to mind when discussing confidential sources (think Deep Throat), journalists' reliance on confidential sources occurs far more regularly and for matters far more commonplace than a presidential scandal. However, attorney-client privilege is codified and regulated; attorneys and clients know the parameters of confidentiality in their relationship and can defer to written rules governing the relationship. ${ }^{18}$

In contrast, the reporter's privilege is far less formal and, thus, far easier to challenge the validity of the agreement to maintain confidentiality. Challenges to a reporter's privilege can come from both sides of a dispute, in either civil or criminal cases. Prosecutors in a criminal case may argue that a reporter is obligated to disclose information related to the commission of a crime, while defense attorneys may argue that their client's "Sixth Amendment right to a fair trial

\footnotetext{
${ }^{16}$ It is important to acknowledge here that, for the sake of congruity throughout this Note, "journalist" will be used as a catch-all term for individuals participating in the act of journalism or reporting. However, terms representing popular ideas, such as "reporter's privilege," will be used in its common parlance rather than modified to reflect the ubiquity of "journalist."

17 The Reporter's Privilege Compendium: An Introduction, REPORTERS COMMITTEE FOR FREedOM OF THE PRESS, http://www.rcfp.org/browse-media-law-resources/guides/reporters-privilege/introduction\#sthash.cyF1KXAQ.dpuf [http://perma.cc/LW5B-LPWB].

${ }^{18}$ For example, Rule 1.6 of the Indiana Rules of Professional Conduct provides both rules governing the attorneyclient privilege and official comments further expounding on the parameters of the attorney-client relationship in regards to confidentiality. See http://www.in.gov/judiciary/rules/prof_conduct/\#_Toc407086483 [http://perma.cc/9V6D-UEUF].
} 
outweighs any First Amendment right that the reporter may have."19 Absent a Supreme Court ruling in favor of establishing a reporter's privilege (which will be discussed at length in Part III), a reporter subpoenaed by the federal government has two choices: disclose the source's identity or confidential information, or risk conviction and incarceration..$^{20}$

Despite a lack of protection at the federal level, journalists enjoy varying levels of protection in state courts. Every state (including the District of Columbia) except Wyoming offers some type of privilege protection for journalists, either derived from case law or enshrined by statute. ${ }^{21}$ These state "shield laws" (laws that provide a figurative shield for the journalist to defend himself or herself from subpoenas) fall under two categories: those that provide "absolute privilege" and those that provide "qualified privilege." Twelve states and the District of Columbia provide journalists an absolute privilege for their sources, ${ }^{22}$ that is, the journalist's right to maintain confidentiality cannot be defeated under any circumstances. For example, Alabama's shield law, which was originally passed in 1935 , provides that "No person . . . shall be compelled to disclose in any legal proceeding or trial ... the sources of any information procured or obtained by him . . . . ${ }^{23}$ Alternatively, twenty-five states provide journalists a qualified privilege for their sources; ${ }^{24}$ such protections establish exceptions where a journalist may not maintain source confidentiality.

\footnotetext{
${ }^{19}$ The Reporter's Privilege Compendium, supra note 17.

${ }^{20} I d$.

21 Tatum, supra note 15.

22 See Shield Laws and Protection of Sources by State, REPORTERS COMM. FOR FREEDOM OF THE PRESS, http://www.rcfp.org/browse-media-law-resources/guides/reporters-privilege/shield-laws [http://perma.cc/8KCHH9LZ] [hereinafter Shield Laws] (last visited Feb. 7, 2015) The twelve states that provide absolute privilege for journalists are: Alabama, Arizona, Kentucky, Maryland, Montana, Nebraska, Nevada, New York, Ohio, Oregon, Pennsylvania, and Washington.

23 ALA. CODE § 12-21-142 (LexisNexis 2015); see also Alabama - Shield Law Statute, REPORTERS COMM. FOR FREEDOM OF THE PRESS, http://www.rcfp.org/alabama-privilege-compendium/shield-law-statute [http://perma.cc/8KCH-H9LZ] (last visited Feb. 7, 2015).

${ }^{24}$ See Shield Laws, supra note 22. The twenty-five states that provide a qualified privilege for journalists are: Alaska, Arkansas, California, Colorado, Connecticut, Delaware, Florida, Georgia, Hawaii, Illinois, Indiana, Louisiana, Maine, Michigan, Minnesota, New Jersey, New Mexico, North Carolina, North Dakota, Oklahoma, Rhode Island, South Carolina, Tennessee, Texas, and Utah.
} 
Although the privilege is qualified, that qualification is a flexible standard depending on the state.

For example, California's shield law only protects journalists who receive a subpoena (rather than

those who are parties to litigation); however, that protection can range from absolute in civil cases

to protection subject to a court balancing test when requested by a criminal defendant. ${ }^{25}$ Compare

that protection to what Indiana offers: absolute privilege for a source's identity, but no protection

of the information received by the journalist. ${ }^{26}$ Some states, such as New Jersey, establish threshold criteria that, once met, require a journalist to disclose confidential sources and information. ${ }^{27}$

\section{DON'T KEEP SECRETS FROM UNCLE SAM: THE UNITED STATES' LACK OF RECOGNITION FOR REPORTER's Privilege in Federal COURT}

\section{A. The First Amendment and Other Considerations}

Proponents of “American Exceptionalism” frequently cite the Unites States' freedom of speech as a hallmark of the freedoms afforded to its citizens. Indeed, the First Amendment to the

25 See California - Absolute or Qualified Privilege, REPORTERS COMM. FOR FREEDOM OF THE PRESS, http://www.rcfp.org/california-privilege-compendium/b-absolute-or-qualified-privilege [http://perma.cc/KYL4XMB7] (last visited Feb. 7, 2015); see Mitchell v. Superior Court, 37 Cal. 3d 268, 279-83 (Cal. 1984). The balancing test, as first adopted for civil cases by the California Supreme Court instructs courts to consider the following factors in determining whether information should be disclosed: (1) "the nature of the litigation and whether the reporter is a party . . .;" (2) "the relevance of the information sought to plaintiff's cause of action . ..;" (3) whether "the plaintiff has exhausted all alternative sources of obtaining the needed information . .." (4) "the importance of protecting confidentiality in the case at hand ...," and (5) "that the alleged defamatory statements are false ..." Subsequently, in Delaney v. Superior Court, the California Supreme Court held that a criminal defendant could compel disclosure of information if the defendant demonstrated a "reasonable possibility the information will materially assist his defense," which courts would determine by weighing the following factors: (1) "[w]heather the unpublished information is confidential or sensitive;" (2) "[t]he interests sought to be protected by the shield law;" (3) "[t]he importance of the information to the criminal defendant;" and (4) "[w]hether there is an alternative source for the unpublished information . . . ."50 Cal. 3d 785, 808 (Cal. 1990). For a more detailed reading about the scope and application of California's shield law, see Kelli L. Sager and Rochelle L. Wilcox, Reporter's Privilege Compendium - California, REPORTERS COMM. FOR FREEDOM OF THE PRESS, http://www.rcfp.org/rcfp/orders/docs/privilege/CA.pdf [http://perma.cc/Z2EN-4T4J] (last visited Mar. 21, 2015).

26 See Indiana - Information and/or Identity of Source, REPORTERS COMM. FOR FREEDOM OF THE PRESS, http://www.rcfp.org/indiana-privilege-compendium/d-information-andor-identity-source [http://perma.cc/68S2ZJRT] (last visited Feb. 7, 2015).

27 See New Jersey - Absolute or Qualified Privilege, REPORTERS COMM. FOR FREEDOM OF THE PRESS, http://www.rcfp.org/new-jersey-privilege-compendium/b-absolute-or-qualified-privilege [http://perma.cc/CRW92EZ8] (last visited Feb. 7, 2015). 
Constitution does provide for free speech and freedom of the press. ${ }^{28}$ This, however, is not an unlimited freedom. The Supreme Court of the United States has, time and time again, qualified the right to both free speech and freedom of the press to protect against libelous speech, ${ }^{29}$ incendiary speech, ${ }^{30}$ and other potentially threatening types of speech that may lead to individual or public safety concerns. ${ }^{31}$

Despite providing its own protections under the Constitution, the United States has voluntarily subjected itself to the constraints of international agreements, including its ratification of the Charter of the Organization of American States (which will be discussed in Part IV). However, when it ratified the Charter, the United States made clear its position on the organization's influence (or indeed lack thereof) in federal jurisprudence:

That the Senate give its advice and consent to ratification of the Charter with the reservation that none of its provisions shall be considered as enlarging the powers of the Federal Government of the United States or limiting the powers of the several states of the Federal Union with respect to any matters recognized under the Constitution as being within the reserved powers of the several states. ${ }^{32}$

The reservations expressed prior to ratification of the Charter are further evidenced by the United States' refusal to be bound by rulings and principles established by the Inter-American Commission on Human Rights (which will be discussed in Part IV). As an examination of case

\footnotetext{
${ }^{28}$ U.S. CONST. amend. I.

${ }^{29}$ See New York Times Co. v. Sullivan, 376 U.S. 254 (1964) (holding that actual malice must be demonstrated before a press report about public officials can be considered libelous); see also Gertz v. Robert Welch, Inc., 418 U.S. 323 (1974) (holding that states can set their own standards for liability for defamatory statements against private individuals that at least meets the minimum of actual malice).

${ }^{30}$ See Schenk v. United States, 249 U.S. 47 (1919) (holding that restrictions on speech inciting lawlessness or panic were permissible under the First Amendment).

${ }^{31}$ See Miller v. California, 413 U.S. 15 (1973) (holding that words "utterly without socially redeeming value" and lacking "serious literary, artistic, political, or scientific value" constituted obscenity and could be restricted); see also Chaplinsky v. New Hampshire, 315 U.S. 568 (1942) (holding that using "fighting words" to breach the peace could be restricted and punished).

32 Dept. of Int. Law, Charter of the Organization of American States (A-41), ORG. OF AM. STATES, http://www.oas.org/dil/treaties_A-41_Charter_of_the_Organization_of_American_States_sign.htm [http://perma.cc/2RYZ-WRP2] (last visited Oct. 18, 2014).
} 
law shows, the Supreme Court has been far more willing to restrict the interpretation of the Constitution rather than "enlarg[e] the powers . . . under the Constitution . . .."33

\section{B. Restricting Source Confidentiality: Branzburg v. Hayes}

The Supreme Court has historically established protections for numerous types of speech and recognized numerous aspects of journalism as protected under the First Amendment. In seminal cases such as New York Times v. Sullivan, ${ }^{34}$ the Court has used its discretion and authority to reaffirm the importance of maintaining a free press for the continued function of a democratic society. However, recently courts have shied away from their earlier precedent of expanding and defining the role and importance of journalism in American society, instead taking a less positive view of the press when they choose to hear press cases. ${ }^{35}$ One notably glaring omission from such protections determined by the Supreme Court is the ability for reporters to guarantee confidentiality to sources who may not otherwise provide information. In Branzburg v. Hayes, ${ }^{36}$ one of the most scrutinized free speech cases in American jurisprudence, the Supreme Court held that requiring reporters to testify before juries does not deprive them of their free speech and free press rights under the First Amendment.

Branzburg brought together three different petitioners, all journalists (albeit in varying types of media), who were brought before grand juries to disclose their confidential sources. ${ }^{37}$ The named petitioner, Branzburg, was compelled to testify after the Louisville Courier-Journal

\footnotetext{
${ }^{33} I d$.

${ }^{34}$ New York Times, supra note 29.

${ }^{35}$ RonNell Andersen Jones, What the Supreme Court Thinks of the Press and Why It Matters, 66 ALA. L. REV. 253, 255 (2014).

${ }^{36}$ Branzburg v. Hayes, 408 U.S. 665, 708-09 (1972).

${ }^{37} I d$.
} 
published an article in 1969 in which he wrote about his interactions with two individuals creating marijuana hashish. ${ }^{38}$ Branzburg indicated in the article that he promised the two subjects profiled that he would not reveal their identities. ${ }^{39}$ Branzburg was subsequently subpoenaed by a grand jury to disclose the identities of the subjects, a request that he refused. ${ }^{40}$ Branzburg was ordered by a state trial judge to answer the jury's inquiry; the judge concluded that Branzburg was not protected by the Kentucky reporters' privilege statute, the Kentucky Constitution, or the First Amendment of the US Constitution. ${ }^{41}$ On appeal, the Kentucky Court of Appeals held that the Kentucky reporters' privilege statute

[A]fford[ed] a newsman the privilege of refusing to divulge the identity of an informant who supplied him with information, but ... did not permit a reporter to refuse to testify about events he had observed personally, including the identities of those persons he had observed. ${ }^{42}$

Branzburg was again subpoenaed in 1971 for a similar article, in which he interviewed subjects about, and observed them ingesting, marijuana. ${ }^{43}$ The trial court again compelled Branzburg to testify, and the Court of Appeals again refused to grant his prohibition. ${ }^{44}$ The Court of Appeals distinguished Branzburg's case from another, which it believed represented "a drastic departure from the generally recognized rule that the sources of information of a newspaper reporter are not privileged under the First Amendment."45

In a 5-4 split decision, Justice Byron White, writing for the majority, declared that the First Amendment "does not invalidate every incidental burdening of the press that may result from the

\footnotetext{
${ }^{38} \mathrm{Id}$. at 667.

${ }^{39} I d$. at 667-68.

${ }^{40} I d$.

${ }^{41} I d$.

${ }^{42}$ Branzburg, 408 U.S. at 668-670.

${ }^{43}$ Id. at 669

${ }^{44} I d$.

${ }^{45} I d$. at 670 (distinguishing Caldwell v. United States, 434 F.2d 1081 (9th Cir. 1970)).
} 
enforcement of civil or criminal statutes of general applicability . . ."46 Justice White observed that the investigative powers granted to grand juries are "necessarily broad" due to its responsibilities for returning "well-founded indictments ...."47 As such, because of the responsibilities placed on grand juries, requiring journalists to testify did not "override the consequential, but uncertain, burden on news gathering that is said to result from insisting that reporters, like other citizens, respond to relevant questions put to them in the course of a valid grand jury investigation or criminal trial." 48

Justice White also refused to acknowledge the flip-side of the reporters' privilege argument: that sources would necessarily want to make sure their identities were protected from further retribution. ${ }^{49}$ Regarding the motives of remaining anonymous, Justice White contended the following:

There is little before us indicating that informants whose interest in avoiding exposure is that it may threaten job security, personal safety, or peace of mind, would in fact be in a worse position, or would think they would be, if they risked placing their trust in public officials as well as reporters. We doubt if the informer who prefers anonymity but is sincerely interested in furnishing evidence of crime will always or very often be deterred by the prospect of dealing with those public authorities characteristically charged with the duty to protect the public interest as well as his. ${ }^{50}$

Justice White reserved equal ire for journalists attempting to maintain source confidentiality following the observation of criminal acts (as Branzburg had done). Rejecting the notion that First Amendment privileges applied to journalists who had observed criminal activity, Justice White

\footnotetext{
${ }^{46} I d$. at $682-83$.

${ }^{47} I d$. at 688.

${ }^{48}$ Branzburg, 408 U.S. at 690-91. See also id. at 695 ("[W]e cannot accept the argument that the public interest in possible future news about crime from undisclosed, unverified sources must take precedence over the public interest in pursuing and prosecuting those crimes reported to the press by informants and in thus deterring the commission of such crimes in the future.").

${ }^{49} I d$. at 693.

${ }^{50} I d$. at 695.
} 
noted that "[t]he crimes of news sources are no less reprehensible and threatening to the public interest when witnessed by a reporter than when they are not." 51

While the majority opinion held that journalists were not necessarily protected from the extensive investigative powers afforded to the grand jury, it is Justice Powell's concurrence that draws the most critical analysis from journalism and legal academia. ${ }^{52}$ Justice Powell sided with the majority (as evidenced from the concurrence); however, unlike the majority, he was unwilling to completely write off the prospect of affording journalists' protections, instead advocating for a case-by-case review to determine whether source confidentiality merited omission from grand jury inquiries. ${ }^{53}$ Justice Powell argued that "[t]he balance of these vital constitutional and societal interests on a case-by-case basis accords with the tried and traditional way of adjudicating such questions." $" 54$ Based on his concurrence, some legal scholars argue that the outcome of the case should be read more as a plurality, rather than majority, opinion, thus opening up the outcome for more critical analysis. ${ }^{55}$ As one scholar observed, "Justice Powell's concurrence, whether he intended it to or not, provided just enough wiggle room for dissatisfied federal courts to use the amorphous guidance in Branzburg to establish their own standards governing the reporter's privilege." 56

Scholars critical of the outcome in Branzburg have embraced the dissent posited by Justice Stewart (joined by Justices Brennan and Marshall), which builds off Justice Powell's advocacy for

\footnotetext{
${ }^{51} I d$. at 692.

52 See Michele Bush Kimball, The Intent Behind the Cryptic Concurrence That Provided a Reporter's Privilege, 13 COMM. L. \& POL'Y 379 (2008) (For an in-depth discussion of Justice Powell's concurrence and its impact on future holdings and legislative action).

${ }^{53}$ Branzburg, 408 U.S. at 710 (Powell, J., concurring).

${ }^{54} \mathrm{Id}$.

55 See Davidson, supra note 8, at 1302 (citing William E. Lee, The Priestly Class: Reflections on a Journalists' Privilege, 23 CARdozo ARTS \& ENT. L. J. 635, 637 (2006)).

56 Peter Meyer, Note, Balco, the Steroids Scandal, and What the Already Fragile Secrecy of Federal Grand Juries Means to the Debate over a Potential Federal Media Shield Law, 83 IND. L.J. 1671 (2008).
} 
case-by-case determination of permission. Justice Stewart expressed grave reservations about the effects of the majority's opinion:

Today's decision will impede the wide-open and robust dissemination of ideas and counterthought which a free press both fosters and protects and which is essential to the success of intelligent self-government. Forcing a reporter before a grand jury will have two retarding effects upon the ear and the pen of the press. Fear of exposure will cause dissidents to communicate less openly to trusted reporters. And, fear of accountability will cause editors and critics to write with more restrained pens. ${ }^{57}$

Justice Stewart argued that, in order to determine whether source confidentiality should be maintained, a three-part analysis should be conducted to decide if privilege exists. ${ }^{58}$ Under Justice Stewart's test,

the government must (1) show that there is probable cause to believe that the newsman has information which is clearly relevant to a specific probable violation of the law; (2) demonstrate that the information sought cannot be obtained by alternative means less destructive of First Amendment rights; and (3) demonstrate a compelling and overriding interest in the information. ${ }^{59}$

As this article will later discuss, implementing such an element test would reaffirm source confidentiality as a fundamental aspect of freedom of speech - a right that can only be overridden by compelling circumstances.

\section{Post-BranzBurg: The Fight for a Federal ShIEld LAW}

Branzburg established a vital precedent for the federal government's investigative and subpoena powers. However, the holding, while impacting, does not restrict further action to define the reporters' privilege and override the court's decision. Although the United States has not yet recognized source confidentiality or the concept of "reporters' privilege" at the federal level,

\footnotetext{
${ }^{57}$ Branzburg, 408 U.S. at 720-21 (Stewart, J., dissenting).

${ }^{58}$ Id. at 743 (Stewart, J., dissenting).

${ }^{59} \mathrm{Id}$.
} 
protections have been instituted by a majority of states. ${ }^{60} \mathrm{~A}$ federal solution resolving the conflicting stances of state shield laws has long been fodder for communications law and journalism scholars. ${ }^{61}$ Primarily, the focus has been on the inadequacy of patchwork protections afforded by the states; namely, that a given protection stops at the state's borders. ${ }^{62}$

Yet the idea of a federal shield law has been met with resistance as well. One of the most prevalent arguments against the enactment of a federal shield law is that such a law would, by its nature, present an undue burden on the Fifth Amendment rights of individuals seeking the information. ${ }^{63}$ Others argue that the institutional protections developed outside of the courtroom provide enough of a bureaucratic roadblock as to render pursuit of a reporter's confidential sources or information as nearly non-existent. ${ }^{64}$ "If there are other avenues to the information, they will be pursued, not only because the regulations require it, but because any alternative means will almost always be faster, easier, and more productive than trying to get the information from a reporter." 65 Additionally at issue is defining who would receive the benefits of the reporter's privilege:

[a] definition that focuses on the function of journalism will, given today's technology, be extremely broad and will allow any individual, under the right

\footnotetext{
60 See Shield Laws and Protection of Sources by State, REPORTERS COMMITTEE FOR FrEEDOM OF THE PRESS, http://www.rcfp.org/browse-media-law-resources/guides/reporters-privilege/shield-laws (last visited Oct. 1, 2014.) [http://perma.cc/H4LY-9LZY].

${ }^{61}$ See generally Davidson, supra note 8 (for a discussion on ideal elements of a federal shield law).

${ }^{62}$ E.g., see Davidson, supra note 8, at 1294 ("So long as there is no federal shield law, federal judges can, in effect, trump state shield laws. Where state legislators have given shield protection, federal judges can thwart state legislative intent.").

${ }^{63}$ Louis J. Capocasale, Comment, Using the Shield as a Sword: An Analysis of How the Current Congressional Proposals for a Reporter's Shield Law Wound the Fifth Amendment, 20 ST. JoHN's J.L. CoMm. 339 (2006) ("By creating an absolute federal reporter's privilege, the current legislative proposals provide newsgatherers with an absolute privilege to withhold evidence that may be valuable or even essential to either the prosecution or vindication of a citizen subject to a federal indictment. Such a sweeping privilege undermines the Fifth Amendment interests the Branzburg Court sought to protect, namely the individual rights of the accused, and the power of government to effectively investigate criminal conduct for the public welfare.").

${ }^{64}$ Randall D. Eliason, The Problems With the Reporter's Privilege, 57 AM. U.L. REV. 1341, 1347 (2008) (“Department of Justice ('DOJ') attorneys are required by regulation to seek the Attorney General's approval for subpoenas to the media, and to demonstrate that the information is essential and all reasonable alternatives have been exhausted.... DOJ subpoenas that actually seek confidential source information are even more rare, averaging only about one a year since 1991.").

${ }^{65} \mathrm{Id}$. at 1352.
} 
circumstances, to claim to be a journalist entitled to invoke the privilege.... But a narrower definition of "journalist" will result in legislative line drawing between different First Amendment speakers, and will raise troubling constitutional questions. ${ }^{66}$

The Supreme Court has not reconsidered the reporter's privilege since its holding in Branzburg. However, the decision is frequently acknowledged in lower courts, both favorably and critically. All federal appellate courts except for the U.S. Court of Appeals for the Sixth Circuit have recognized the existence of some type of reporter's privilege, rooted in either the First Amendment or common law. ${ }^{67}$ Finding the privilege to exist in common law is an important holding, as the Branzburg court focused primarily on the First Amendment arguments for the existence of such a privilege. For example, in Riley v. City of Chester,${ }^{68}$ the U.S. Court of Appeals for the Third Circuit held that "Branzburg's suggestion that the First Amendment protected newsgathering and the obvious links between effective newsgathering, confidential sources, and an informed public weighed in favor of the privilege." 69 At issue in the case was a reporter's refusal to disclose a source that had provided information about internal investigations regarding a mayoral candidate while the candidate was a police officer for the city. ${ }^{70}$ The reporter cited Pennsylvania's state shield law as justification for refusing to disclose who provided her with the information. ${ }^{71}$ The court, in finding that the reporter did not have to disclose her source because the information sought had only "marginal relevance"72 to the plaintiff's suit, concluded that "[t]he strong public policy [behind Pennsylvania's shield law] which supports the unfettered

\footnotetext{
${ }^{66}$ Id. at 1367.

67 Anthony L. Fargo, Rights and Interpretation: Common Law or Shield Law? How Rule 501 Could Solve the Journalist's Privilege Problem, 33 WM. MitcheLl L. REV. 1347, 1359 (2007).

${ }^{68}$ Riley v. City of Chester, 612 F.2d 708 (3d. Cir. 1979).

${ }^{69}$ Fargo, Rights and Interpretation, supra note 67, at 1360-61.

${ }^{70}$ Riley, 612 F.2d at 710.

${ }^{71}$ Id. at 711.

${ }^{72} \mathrm{Id}$. at 718 .
} 
communication to the public of information, comment, and opinion and the Constitutional dimension of that policy... lead us to conclude that journalists have a federal common law privilege, albeit qualified, to refuse to divulge their sources."73

Similarly (and favorably citing the Riley decision), the U.S. Court of Appeals for the First Circuit remanded in Bruno \& Stillman, Inc. v. Globe Newspaper Co. ${ }^{74}$ a lower court dismissal of a negligence charge against a newspaper, concluding that the district court needed to reassess the balancing test it applied to determine whether a reporter was obligated to disclose notes about confidential sources. The lower court dismissed a charge of negligence against the newspaper, stemming from a story written about malfunction instances of the plaintiff manufacturer's boats, after finding that its applied criteria to compel disclosure of notes was satisfied. ${ }^{75}$ The appellate court, considering the Riley outcome, concluded that "the balancing process [conducted by the district court] was not conducted with sufficient awareness of the contesting values, the factors to be considered, and the options available to the court" regarding the plaintiff's needs for the nondisclosed information in question. ${ }^{76}$

Conversely, in In re Grand Jury Proceedings,${ }^{77}$ the U.S. Court of Appeals for the Sixth Circuit split from other federal circuits in holding that, absent state statutory protections preventing disclosure of confidential sources, a Michigan television reporter was, on the balance of interests, not entitled to quash a subpoena requiring disclosure of his confidential sources in a gang-related crime. The reporter was subpoenaed to compel disclosure of information relating to the identity of an assailant in a police officer's murder that he had gathered in the process of filming gang

\footnotetext{
${ }^{73} I d$. at 715 .

${ }^{74}$ Bruno \& Stillman, Inc. v. Globe Newspaper Co., 633 F.2d 583 (1 ${ }^{\text {st }}$ Cir. 1980).

${ }^{75} I d$. at 586.

${ }^{76} \mathrm{Id}$. at 599.

${ }^{77}$ Storer Communs. Inc. v. Giovan (In re Grand Jury Proceedings), 810 F.2d 580 (6th Cir. 1987).
} 
members for a report. The state trial court concluded that “Michigan's statutory news reporters' privilege does not include television news reporters, and ruled that [the reporter] had no constitutional privilege to refuse to divulge to the grand jury the material sought."78 On appeal, the federal appellate court declined to apply at the reporter's insistence Justice Powell's Branzburg concurrence, instead concluding that the Branzburg holding did not afford the reporter protection from disclosing his confidential information. ${ }^{79}$ The court found that "Justice Powell's concurring opinion is entirely consistent with the majority opinion, and neither limits nor expands upon its holding . . . ." ${ }^{80}$ In addition, the court, after considering the legislative history of Michigan's statutory protections for newspaper reporters, found that the reporter was not denied his rights under the Equal Protection Clause of the Fourteenth Amendment by failing to apply the reporter's broad interpretation of qualified individuals under the statute. ${ }^{81}$

Due in part to the Supreme Court's lack of jurisdiction following its decision in Branzburg, as well as in consideration to the states' decision to enact its own protections, Congress has considered numerous proposals for a federal shield law in the past decade. ${ }^{82}$ The most recent attempt, the Free Flow of Information Act of 2013, was authored by Sen. Charles Schumer of New York. ${ }^{83}$ The bill outlined an expansive view of who would qualify for protection under the act as a "covered journalist," including student journalists and freelance "agent[s]" of publications, and more generally any individual who "at the inception of the process of gathering the news or

\footnotetext{
${ }^{78} \mathrm{Id}$. at 583 .

${ }^{79} \mathrm{Id}$. at 584 .

${ }^{80} \mathrm{Id}$. at 585 .

${ }^{81} \mathrm{Id}$. at 588.

${ }^{82}$ See Anthony L. Fargo, Analyzing Federal Shield Law Proposals: What Congress Can Learn from the States, 11 COMM. L. \& POL'Y 35 (2006).

83 Free Flow of Information Act of 2013, S. 987, 113th Cong. (2013), available at https://www.congress.gov/bill/113th-congress/senate-bill/987/summary/100688 (last visited Feb. 8, 2015)[ http://perma.cc/5KPU-B9F4].
} 
information sought, had the primary intent to investigate issues or events and procure material in order to disseminate news to the public and regularly conducted interviews, reviewed documents, captured images of events, or directly observed event." 84 The legislation established a qualified privilege, with different thresholds of criteria required to override the privilege. In a federal criminal case, the information and source identities of "covered journalists" would be protected unless a federal judge determined that, among other criteria, the protected information was "essential to the investigation or prosecution or to the defense against the prosecution..." and that "the covered journalist ha[d] not established by clear and convincing evidence that disclosure would be contrary to public interest, including the interest in gathering and disseminating information or news as well as maintaining the free flow of information and the public interest in compelling disclosure, including the extent of any harm to national security." 85 In a federal civil case, the information and source identities of "covered journalists" would be protected unless a federal judge determined that the information sought from the journalist was "essential to the resolution of the matter" and that the disclosure "clearly outweigh[ed] the public interest in gathering and disseminating the information or news at issue and maintaining the free flow of information." 86

Although the legislation provided a decidedly easy threshold for the government to compel disclosure of confidential information, the Free Flow of Information Act did establish fundamental requirements for the protection of journalists, most specifically the range of individuals protected under the privilege. It was not without support, either; the legislation garnered twenty-seven cosponsors, including both Republican and Democratic senators. ${ }^{87}$ Sen. Schumer, the bill's author,

\footnotetext{
${ }^{84} I d$.

${ }^{85} I d$.

${ }^{86} \mathrm{Id}$.

${ }^{87} I d$.
} 
said in an interview in March 2014 that the likelihood of getting at least some type of federal shield law passed was "very large," noting that the bill had the sixty votes needed to pass through the Senate without threat of a filibuster. ${ }^{88}$ However, despite Schumer's efforts and optimism, Congress has still not voted on a federal shield law. The legislation was last placed on the Senate calendar in November 2013; it has not seen any legislative action since then, despite numerous calls from outside interest groups requesting a vote. ${ }^{89}$

\section{BACKground: The ORganization OF AMERICAN STATES AND SourCE}

\section{CONFIDENTIALity}

\section{A. Founding and Structure of the Organization of American States}

For most laymen, the European Union comes to mind almost exclusively when one recalls a multinational governmental organization tasked with steering and adjudicating policy decisions for its member states. However, the United States is party to (and indeed hosts) a similar - albeit less constraining - membership: the Organization of American States (hereafter OAS). ${ }^{90}$ Structured in a generally similar model to its transatlantic peer the EU, the OAS is the "world's oldest regional organization . ..."91 The OAS dates back to 1889, when the First International Conference of American States approved the establishment of the International Union of American

\footnotetext{
${ }^{88}$ Joe Pompeo, Schumer predicts shield law will pass this year, CAPITAL NEW YORK (Mar. 21, 2014, 12:23 PM), http://www.capitalnewyork.com/article/media/2014/03/8542441/schumer-predicts-shield-law-will-pass-year [http://perma.cc/UX6H-XSSS ].

${ }^{89}$ See Sean O'Leary, 75 Media Companies and Journalism Organizations Call for a Senate Floor Vote on the Federal Shield Bill to Protect Journalists' Confidential Sources, NewSPAPER ASSOCIATION OF AMERICA, June 11, 2014, http://www.naa.org/News-and-Media/Press-Center/Archives/2014/Shield-Law-Senate-Vote-Coalition-Letter.aspx [http://perma.cc/BH6M-KG44]; see also Editorial, Revive the Free Flow of Information Act, L.A. TIMES, June 19, 2014, http://www.latimes.com/opinion/editorials/la-ed-shield-20140619-story.html.[http://perma.cc/EHY2-PQ2C].

${ }^{90}$ See generally Who We Are, ORG. OF AM. STATES, http://www.oas.org/en/about/who_we_are.asp (last visited Oct. 18, 2014).[http://perma.cc/S555-EJW7]. The OAS is headquartered in Washington, D.C. See Our Locations, ORG. OF AM. STATES, http://www.oas.org/en/about/our_locations.asp (last visited Nov. 7, 2014) [http://perma.cc/NZ6JRZNE].

${ }^{91}$ Who We Are, supra note 90.
} 
Republics (the organization's predecessor). ${ }^{92}$ The OAS in its current form was established in 1948 by the Charter of the OAS. ${ }^{93}$ Twenty-one nation-states signed the original charter, including the United States. ${ }^{94}$ After four amendments, ${ }^{95}$ the most current version of the charter has been ratified by all thirty-five "independent states of the Americas." 96

The OAS establishes four "pillars" to "implement its essential purposes" - democracy, human rights, security, and development. ${ }^{97}$ Of these pillars, the primary focus of this Note is the OAS's development and implementation of human rights. The OAS monitors the human rights activities of its member nations through the Inter-American Commission on Human Rights (IACHR), which was established in 1959 as the autonomous branch for the regulation of human rights. ${ }^{98}$ Actions taken and decisions made by the IACHR are influenced by the commission's three guiding directives: "the individual petition system;" "monitoring of the human rights situation in the Member States...;" and "the attention devoted to priority thematic areas."99

The American Convention on Human Rights (hereafter the Convention), which establishes the Inter-American Court of Human Rights and "defines the functions and procedures of both the Commission and the Court" was adopted in $1969 .{ }^{100}$ Of particular relevance to this Note, Article

92 Id.

${ }^{93} I d$.

94 The original signatories are: Argentina, Bolivia, Brazil, Chile, Columbia, Costa Rica, Cuba, the Dominican Republic, Ecuador, El Salvador, Guatemala, Haiti, Honduras, Mexico, Nicaragua, Panama, Paraguay, Peru, the United States, Uruguay, and Venezuela. For ratification information, see General Information of the Treaty: A-41, Charter of the Organization of American States, http://www.oas.org/dil/treaties_A41_Charter_of_the_Organization_of_American_States_sign.htm (last visited Oct. 18, 2014) [http://perma.cc/2XGD4JPT]. Costa Rica was the first nation to formally ratify the Charter on Oct. 30, 1948. Id.

95 The Protocol of Buenos Aires (signed in 1967); the Protocol of Cartegena de Indias (signed in 1985); the Protocol of Managua (signed in 1993); and the Protocol of Washington (signed in 1992). See Who We Are, supra note 86.

${ }^{96}$ Who We Are, supra note 90 .

${ }^{97}$ What We Do, ORG. OF AM. STATES, http://www.oas.org/en/about/what_we_do.asp (last visited Oct. 16, 2014) [http://perma.cc/D9F5-3M3Q].

98 What is the IACHR? ORG. OF AM. STATES, http://www.oas.org/en/iachr/mandate/what.asp (last visited Oct. 18, 2014) [http://perma.cc/EH82-B8BX].

${ }^{99} \mathrm{Id}$.

${ }^{100} I d$. 
13 of the Convention provides the right to freedom of expression for citizens of its member nations. ${ }^{101}$ The Convention states that "[e]veryone has the right to freedom of thought and expression. This right includes freedom to seek, receive, and impart information and ideas of all kinds, regardless of frontiers, either orally, in writing, in print, in the form of art, or through any other medium of one's choice."102 The Convention qualifies that right, however, declaring that exercising the right to free expression is not "subject to prior censorship" but can be curtailed to maintain "respect for the rights or reputations of others" and/or "the protection of national security, public order, or public health or morals." ${ }^{\prime 103}$ Crucially, the Convention provides that

[t]he right of expression may not be restricted by indirect methods or means, such as the abuse of government or private controls over newsprint, radio broadcasting frequencies, or equipment used in the dissemination of information, or by any other means tending to impede the communication and circulation of ideas and opinions (emphasis added). ${ }^{104}$

As of 1997, twenty-five nations have ratified the Convention. ${ }^{105}$ Noticeably absent from the list of ratifying nations are two of the most high-profile, if not most powerful, member nations of the OAS: Canada and the United States.

\section{B. The Inter-American Declaration of Principles on Human Rights}

The IACHR recognizes freedom of expression broadly, pursuant to the terms of the Convention. However, the IACHR further expounded on what constitutes the freedom of expression with the adoption of the Inter-American Declaration of Principles on Human Rights

\footnotetext{
${ }^{101}$ Organization of American States, American Convention on Human Rights, art. 13, Nov. 22, 1969, O.A.S.T.S. No. 36, 1144 U.N.T.S. 123, http://www.cidh.oas.org/Basicos/English/Basic3.American\%20Convention.htm [http://perma.cc/DB7L-JETJ].

102 Id. at 1 II 1.

${ }^{103} I d$. at $\mathbb{I} 2$.

${ }^{104} \mathrm{Id}$. at $\mathrm{II} 3$.

${ }^{105}$ What is the IACHR, supra note 98. The ratifying nations are: Argentina, Barbados, Brazil, Bolivia, Chile, Colombia, Costa Rica, Dominica, Dominican Republic, Ecuador, El Salvador, Grenada, Guatemala, Haiti, Honduras, Jamaica, Mexico, Nicaragua, Panama, Paraguay, Peru, Suriname, Trinidad and Tobago, Uruguay and Venezuela.
} 
(hereafter the IADPHR) in 2000. ${ }^{106}$ Among other protections, Article 8 of the IADPHR establishes the right to source confidentiality: "[e]very social communicator has the right to keep his or her source of information, notes, personal and professional archives confidential." ${ }^{\text {107 }}$ Additional guidance clarifying the Declaration provides that this right of confidentiality establishes the protection for "every social communicator to refuse to disclose sources of information and research findings to private entities, third parties, or government or legal authorities . . ."108 It further provides that the right "does not constitute a duty, as the social communicator does not have the obligation to protect the confidentiality of information sources, except for reasons of professional conduct and ethics." ${ }^{109}$ The interpretation of the Declaration states that the underlying rationale to the right of confidentiality acknowledges that

'in the scope of [the social communicator's] work to supply the public with the information necessary to satisfy the right to inform, the journalist is providing an important public service when he or she collects and disseminates the information that would not be made known without protecting the confidentiality of the sources (emphasis added). ${ }^{110}$

Applying principles from both the American Convention of Human Rights and the InterAmerican Declaration of Principles on Freedom of Expression, the Inter-American Court of Human Rights has been able to implement and enforce press freedoms for journalists against government efforts of ratifying nations to restrict their press activities and actors. ${ }^{111}$ However, as

106 Basic Documents in the Inter-American System - Introduction, ORG. OF AM. STATES, http://www.oas.org/en/iachr/mandate/Basics/intro.asp (last visited Oct. 18, 2014) [http://perma.cc/2A3W-KSC5].

107 Declaration of Principles on Freedom of Expression, art. http://www.oas.org/en/iachr/expression/showarticle.asp?artID=26 (last visited Oct. 18, 2014) [http://perma.cc/4E4KPS5C].

108 Background and Interpretation of the Declaration of Principles, ORG. OF AM. STATES, at II 36, http://www.oas.org/en/iachr/expression/showarticle.asp?artID=132\&lID=1（last visited Oct. 19, 2014) [http://perma.cc/YGLR-FXCK].

${ }^{109} \mathrm{Id}$.

${ }^{110} \mathrm{Id}$. at $\mathbb{I} 37$.

111 See generally Jo M. Pascqualucci, Criminal Defamation and the Evolution of the Doctrine of Freedom of Expression in International Law: Comparative Jurisprudence of the Inter-American Court of Human Rights, 39 
of 2010, only twenty-one nations recognize the court's jurisdiction and follow its adjudication. ${ }^{112}$ As with the Convention, neither Canada nor the United States recognize the jurisdiction of the court nor the right of confidentiality, instead restricting the right based on judicial interpretations of their respective national charter documents.

\section{A Different APPROACH: CANADA AND ThE EUROPEAN Union's JUdicial}

\section{ObSERVATIONS OF QuAlifiEd SourCe CONFIDENTIALITY}

\section{A. Canada}

Canada, another powerful American nation that has not ratified the American Convention on Human Rights or the Inter-American Declaration of Principles on Freedom of Expression, has established a national fundamental right to free speech that, similar to the First Amendment in the United States, extends to journalists. The Canadian Charter of Rights and Freedoms provides that "[e]veryone has the following fundamental freedoms ... of thought, belief, opinion and expression, including freedom of the press and other media of communication ...."113 However, similar to the Branzburg ruling in the United States, Canadian courts have played an active role in qualifying the right to free expression.

\section{i. Privileged Communication in Canada: $R$ v. Gruenke}

To understand communication rights as they exist in Canada, one must first look to a defining case in determining whether communication is "privileged." In $R$ v. Gruenke, ${ }^{114}$ the Canadian Supreme Court declared that communications between two individuals could be

VAND. J. TRANSNAT'L L. 379 (2006) (discussing the role of the Inter-American Court on Human Rights and difficulties responding to the backlog of cases brought before the court).

112 Basic Documents, supra note 106. The 21 nations are: Argentina, Barbados, Bolivia, Brazil, Chile, Colombia, Costa Rica, Dominican Republic, Ecuador, El Salvador, Guatemala, Haiti, Honduras, Mexico, Nicaragua, Panama, Paraguay, Peru, Suriname, Uruguay, and Venezuela.

${ }^{113}$ Canadian Charter of Rights and Freedoms, Part I of the Constitution Act, 1982, § 2, being Schedule B to the Canada Act, 1982, c.11 (U.K.)

${ }^{114}$ R. v. Gruenke, [1991] 3 S.C.R. 263, 291 (Can.) 
privileged (and thus immune from discovery) under a specific set of circumstances. The case came before the Court on appeal from the appellant, Gruenke, who was convicted of first degree murder after killing her harasser. ${ }^{115}$ Gruenke, a reflexologist, lived for a time with a client, Philip Barnett, in a platonic relationship; however, Gruenke moved out when Barnett began making sexual advances towards her. ${ }^{116}$ Gruenke also began visiting the Victorious Faith Centre church to seek emotional help. ${ }^{117}$ At trial, Gruenke testified that when Barnett came to visit her, and attempted to drive away with her in his car without her consent, Gruenke struck him with a piece of wood. ${ }^{118}$ She could not recall at trial any other details, aside from her boyfriend approaching her and Barnett, then the two of them leaving Barnett as he was covered in blood. ${ }^{119}$ The trial judge ruled admissible evidence of communication between a church layperson, the church pastor, and Gruenke; the evidence revealed that two days after Barnett was found dead, the pastor had a conversation with Gruenke in which she admitted planning to kill, and indeed killing, Barnett to stop his harassment. ${ }^{120}$

The Supreme Court found at issue the question of whether conversation between an individual and a clergyman or religious figure could be privileged and therefore protected from discovery and admission as evidence. ${ }^{121}$ In order to resolve issues of determining whether a communication was privileged in general, the Court established the "Wigmore" test. ${ }^{122}$ The test requires that the following four factors be met:

(1) the communications must originate in a confidence that they will not be disclosed; (2) this element of confidentiality must be essential to the full and

\footnotetext{
${ }^{115} I d$. at $263-64$.

${ }^{116} I d$. at 273 .

${ }^{117} I d$. at 273-74.

${ }^{118} \mathrm{Id}$. at 274 .

${ }^{119} \mathrm{Id}$.

${ }^{120}$ Gruenke, supra note 114, at 275.

${ }^{121} \mathrm{Id}$. at 264 .

${ }^{122} I d$. at 310 .
} 
satisfactory maintenance of the relation between parties; (3) the relation must be one which in the opinion of the community ought to be sedulously fostered; and (4) the injury that would inure to the relation by the disclosure of the communications must be greater than the benefit thereby gained for the correct disposal of litigation. ${ }^{123}$

Development of the test would prove to be critical in later analysis of privileged communication and set Canada on a path towards recognizing source confidentiality.

\section{ii. Contemporary Privilege: R. v. National Post}

With the establishment of the "Wigmore" test, the Canadian Supreme Court outlined conditions in which communication could be found privileged. In 2010, the Court in $R v$. National Post applied the test to determine whether confidential communications between a source and reporter qualified as privileged communication. ${ }^{124}$ In National Post, the Court determined that a particular confidential communication between a reporter for the National Post and a source regarding a document implicating the Canadian prime minister of a conflict of interest did not satisfy the Wigmore test to keep the information confidential. ${ }^{125}$ The reporter for the National Post, M, was investigating the former Prime Minister of Canada, C, regarding alleged improprieties of a federal bank loan to a hotel that owed a debt to C's family investment company. ${ }^{126} \mathrm{X}$ (the confidential source) provided M with a document purported to be the bank's authorization of the loan on the condition of "blanket, unconditional... confidentiality." ${ }^{127} \mathrm{M}$ then faxed copies of the document to the bank, C's office, and a lawyer for C to determine the accuracy of the document. ${ }^{128}$ All three declared the document to be a forgery. ${ }^{129}$ After $\mathrm{M}$ met $\mathrm{X}$ in person,

${ }^{123} I d$. The test appears to originate from 8 JOHN HENRY Wigmore, EvidENCE IN TRIALS AT COMmON LAW (2nd ed. 1961).

${ }^{124}$ R. v. National Post, [2010] S.C.R. 447, 482 (Can.).

${ }^{125} I d$. at $482-83$.

${ }^{126} \mathrm{Id}$. at 494.

${ }^{127} I d$.

${ }^{128} I d$. at 495 .

${ }^{129} I d$. 
$\mathrm{X}$ expressed his belief that the document was genuine requested that the document be destroyed for fear that fingerprints on the document might link him to the disclosure. ${ }^{130} \mathrm{M}$ refused to destroy the document but promised $\mathrm{X}$ that their confidentiality agreement remained in place. ${ }^{131}$ Police, at the request of the bank in question, ordered from the newspaper the document as evidence of forgery and "utterance" (circulation) of the modified records. ${ }^{132}$ The newspaper refused to surrender the document; $\mathrm{M}$ additionally refused to identify $\mathrm{X}$ to the police. ${ }^{133} \mathrm{~A}$ warrant was issued giving the newspaper one month to disclose the document; the newspaper responded by filing suit to squash the document. ${ }^{134}$ The trial court, setting aside the warrant, found that while "there was sufficient information to conclude the document was a forgery ... there was only a remote and speculative possibility that disclosure of the document . . would advance a criminal investigation."135 The Court of Appeals reversed, and appellants sought review by the Supreme Court. ${ }^{136}$

The Canadian Supreme Court held that the warrant was properly issued and that the newspaper did not satisfy the fourth factor of the "Wigmore" test required to qualify the document as privileged. ${ }^{137}$ The Court did, however, explicitly acknowledge that privilege could exist on a case-by-case basis, finding that "[t]he Wigmore criteria provide a workable structure within which to assess, in light of society's evolving values, the sometimes-competing interests of free expression and the administration of justice and other values that promote the public interest."138

\footnotetext{
${ }^{130}$ National Post, supra note 124, at 496.

${ }^{131} \mathrm{Id}$.

${ }^{132} \mathrm{Id}$.

${ }^{133} \mathrm{Id}$.

${ }^{134} \mathrm{Id}$.

${ }^{135} \mathrm{Id}$.

${ }^{136}$ National Post, supra note 124.

${ }^{137}$ Id.

${ }^{138}$ Id.
} 
The Court noted that, in order to meet the criteria of the "Wigmore" test, a media organization or reporter must meet all criteria, including "proving that the public interest in protecting a secret source outweighs the public interest in a criminal investigation."139 Claims under the "Wigmore" test for media parties will also be held under scrutiny for "the nature and seriousness of the [offense] under investigation, and the probative value of the evidence sought to be obtained measured against the public interest in respecting the journalist's promise of confidentiality."140 The Court, in finding against the National Post, thus proposed a strict, albeit permissive, analysis of privileged communication for future media claims: "Until the media have met all four criteria, no privilege arises and the evidence is presumptively compellable and admissible. Therefore, no journalist can give a secret source an absolute assurance of confidentiality."141

\section{B. The European Union}

Although numerous actors in the United States have indicated a desire to establish some type of federal protection for source confidentiality, and although Canadian courts have indicated a willingness to recognize source confidentiality as a fundamental right, both nations lag behind many of their transatlantic peers. The EU (and therefore any participating nation) has recognized source confidentiality (and through it, reporters' privilege) as an aspect of the fundamental right to free expression. Article 10 of the European Convention on Human Rights establishes a freedom of expression for European citizens - including journalists: "[ $\mathrm{t}]$ his right shall include freedom to hold opinions and to receive and impart information and ideas without interference by public authority and regardless of frontiers." 142 The Article does qualify the right, subjecting it to "such

\footnotetext{
${ }^{139} I d$. Note that this test, developed in 2010, echoes the test established by Justice Stewart's Branzburg dissent more than 30 years prior. (maybe reference where in the note the Branzburg case comes from)

${ }^{140}$ Id.

${ }^{141} \mathrm{Id}$.

${ }^{142}$ European Convention on Human Rights art. 10, I[ 1, June 1, 2010, C.E.T.S. No 194.
} 
formalities, conditions, restrictions or penalties as prescribed by law and are necessary in a democratic society" in order to allow nations to maintain national security, prevent crime, protect "the reputation of rights of others," maintain the "authority and impartiality of the judiciary," and, importantly, prevent the "disclosure of information received in confidence . ..." However, the explicit inclusion of the goal of "preventing the disclosure of information received in confidence" sets apart the article from the First Amendment of the U.S. Constitution and Section 2 of the Canadian Charter of Rights and Freedoms (as previously discussed).

In 1996, the European Court on Human Rights reaffirmed the right of journalists to maintain confidential sources in the seminal case Goodwin v. United Kingdom. ${ }^{144}$ In Goodwin, the Court overruled the U.K.'s order compelling a journalist to disclose his confidential source, deeming his right to maintain such a source as "necessary in a democratic society" in accordance with Article 10. ${ }^{145}$ The journalist in question received information from a confidential source about a company's financial mismanagement and contacted the company to verify the claims. ${ }^{146}$ The company requested, and U.K. courts administered, an injunction barring the journalist or his publication from releasing the information (which was extended to restrict all national media from publishing the information), as well as requiring the disclosure of the source's identity by the reporter. ${ }^{147}$ The Court observed that "[p]rotection of journalistic sources is one of the basic conditions for press freedom, as is reflected in the laws and professional codes of conduct in a number of Contracting States and is affirmed in several international instruments on journalistic

\footnotetext{
${ }^{143}$ Id. II 2.

144 Goodwin v. U.K., 22 Eur. Ct. H.R. 123 (1996), http://hudoc.echr.coe.int/sites/eng/pages/search.aspx?i=00157974\#\{"itemid":["001-57974"]\}[https://perma.cc/3JN6-G5V6?type=source].

145 Id. para. 46.

${ }^{146} \mathrm{Id}$.

${ }^{147}$ Id.
} 
freedoms . ..."148 Absent guaranteed protections for maintaining confidentiality, the Court noted that sources "may be deterred from assisting the press in informing the public on matters of public interest." 149 Thus, the Court expressed concern that "the vital public-watchdog role of the press may be undermined and the ability of the press to provide accurate and reliable information may be adversely affected." ${ }^{150}$ The Court found that the company was afforded adequate protection by UK courts when it received an injunction barring the publication of the confidential materials, and that requiring disclosure overstepped the reasonable protections afforded to the company. ${ }^{151}$

\section{AnAlysis: Why RATify a Treaty?}

This Note has thus far posited that there exists in the Americas a structured and definitive law determining that source confidentiality exists as a human right ${ }^{152}-\mathrm{a}$ law that is accepted and followed by twenty-one member nations of the OAS. ${ }^{153}$ The reservations posited by the United States - an unwillingness to "expand the scope ... of the Constitution ..." seems to directly counter the spirit of the Bill of Rights, the first tenet of which establishes the freedom of speech and freedom of the press at issue here. Expanding the scope of defined human rights (which is the stated purpose of the Bill of Rights' existence) does not appear to be either expanding the scope of federal government or restricting states' rights - both fears acknowledged by the United States' reservations when ratifying the Charter of the OAS. ${ }^{154}$ Indeed, a majority of states have established

\footnotetext{
${ }^{148}$ Id. para. 39.

${ }^{149} \mathrm{Id}$.

${ }^{150}$ Goodwin, supra note 144.

151 Id. para. 42.

152 Declaration of Principles, supra note 107.

${ }^{153}$ Basic Documents, supra note 106.

${ }^{154}$ See Charter of the Organization of American States, supra note 32.
} 
reporters' privilege and source confidentiality protections, some dating back more than a century. ${ }^{155}$

If the first step towards recovery is acknowledging that a problem exists, legal scholars (and indeed Congress) have taken the first step. A federal shield law proposal (or lack thereof) is popular fodder for both legal and journalism academics, who challenge and dispute the notion that the United States cannot enact at the federal level legislation that a majority of states have enforced for years - some for over a century. And members of Congress seem to recognize that there is both a problem and a venue for change; as recently as 2013, legislation has been introduced to establish a federal shield law. ${ }^{156}$ But, suffering the same fate as many proposals before it, the legislation seems doomed to wither on the vine as it languishes in the Senate.

All of this seems to spell doom for the prospects of a federal shield law for years to come. With a gridlocked federal government unable to agree on a slate of legislation far more crucial (at least in the eyes of a sizeable number of the population) to maintaining the national status quo, a federal shield law's passage seems as distant as it has ever been (barring, of course, a national tragedy or scandal resulting in a public outcry for passage of the law). ${ }^{157}$ Meanwhile, the Supreme Court does not appear willing to reinterpret the idea of reporter's privilege in the near future; by passing on its opportunity to hear Risen's case in 2014, the Court all but committed itself to maintaining the precedent established in Branzburg. ${ }^{158}$

\footnotetext{
${ }^{155}$ Maryland passed the first state "shield" law, protecting journalists from disclosing their sources, in 1896. See Fargo, Analyzing Federal Shield Law Proposals, supra note 82, at 46. As of 2014, 37 states and the District of Columbia provide some type of protection for journalists regarding source disclosure. See Shield Laws, supra note 21.

${ }^{156}$ See Free Flow of Information Act, supra note 83.

157 The inverse of such a situation occurred in 2009, when the Wikileaks disclosure of confidential government documents undercut efforts made by both the House and Senate to enact a federal shield law. See Rem Rieder, Shield law for journalists a gridlock casualty, USA TODAY (Sept. 22, 2014, 6:23 PM), http://www.usatoday.com/story/money/columnist/rieder/2014/09/22/federal-shield-law-for-journalists-doomed$\mathrm{a} / 16050353 /$.

${ }^{158}$ Liptak, supra note 1.
} 
Yet diminished expectations for federal legislation enacted by Congress's own volition bring forward another alternative: forcing Congress's hand to craft legislation reflecting its own goals by ratifying an existing structure for qualified reporter's privilege as a baseline for establishing federal protections for journalists. The IADPHR presents a perfect opportunity for the United States to consign itself to a structure by which it could establish its own qualified criteria for press freedoms.

Crucially, one of the most appealing aspects of ratifying the IADPHR is the opportunity to bypass the bicameralism that has doomed federal legislation in recent years. Article II of the United States Constitution provides that a president may enter into treaties with two-thirds consent from the Senate. ${ }^{159}$ Despite its pursuit of criminal charges in leak cases, the Obama administration has been an advocate for the establishment of a federal shield law, ${ }^{160}$ and asking for the consent of two-thirds of the Senate is at this point a far more plausible path to recognition of a reporter's privilege at the federal level than relying on the Senate and House of Representatives to agree to statutory terms creating a federal reporter's privilege. ${ }^{161}$

Ratification of the treaty also gives Congress a reason to move forward legislation clarifying and qualifying the provisions of the IADPHR. One of the chief differences between previous legislation proposed by Congress and provisions in the IADPHR is the use of the term "social communicator" to describe individuals protected by the declaration. The Free Flow of Information Act of 2013, the Senate's most recent attempt at advancing a federal shield law, provided protection for an individual acting as a "covered journalist"162 - a wide term, but not

\footnotetext{
159 See Art. II $\S 2$ Cl. 2.

${ }^{160}$ Liptak, supra note 1.

${ }^{161}$ Rieder, supra note 157. Rieder notes that both the Senate (with Schumer's proposed bill) and the House (with an amendment to an unrelated appropriations bill) both took action towards a federal shield law; however, given the current political circumstances in Congress, a bicameral effort to enact a federal shield law seems at best unlikely.

${ }^{162}$ See Free Flow of Information Act, supra note 83.
} 
nearly as encompassing as the social communicator protected by the IADPHR. The distinction between a "covered journalist" and "social communicator" might be of benefit to Congress because it lessens the concern of defining an exclusive privilege. As Dr. Anthony Fargo notes in his analysis of federal shield law proposals, "[d]efining a class of persons who would receive special protection from providing evidence to grand juries would be tricky at best and unconstitutional at worst because it would force judges to decide who qualified and who did not . $\ldots " 163$

Embracing by Congressional inaction the term "social communicator" might be beneficial to accommodate the ever-changing media landscape as more traditional media roles are transferred to the Internet. One of the most pervasive points of contention in contemporary discussions of a federal shield law is the scope of its protections to non-traditional media actors - namely, bloggers and the like. As blogging and other types of "instant journalism" become more commonplace, the individuals who engage in such media actions must be regarded as more than mere citizens. ${ }^{164}$ Indeed, blogging now encompasses individuals who would otherwise be regarded as "traditional journalists" as established media outlets utilize various means to produce and disseminate the news. ${ }^{165}$ Blogging and other "new media" ventures provide a cheaper, more immediate means to disseminate information, ${ }^{166}$ allowing more information to be presented by more "reporters" (adopting a broad interpretation of the word). Advocates for the inclusion of bloggers and other non-traditional reporters argue that the technological advances have redefined the criteria such that

\footnotetext{
${ }^{163}$ Fargo, Analyzing Federal Shield Law Proposals, supra note 82, at 56.

${ }^{164}$ Larry E. Ribstein, From Bricks to Pajamas: The Law and Economics of Amateur Journalism, 48 WM. \& MARY L. REV. 185, 193 (2006) ("Though bloggers tend to focus more on analysis or opinion than reporting of facts, they are no less 'journalists' in the broad sense of the term.").

${ }^{165}$ Lauren Guicheteau, What is the Media in the Age of the Internet? Defamation Law and the Blogosphere, 8 WASH. J.L. TECH. \& ARTS 573, 576 (2013).

${ }^{166}$ Ribstein, supra note 164, at 193. ('Blogs are a classic example of 'cheap speech.' In terms of capital investment, blogging requires no more than a computer, Internet access, and, perhaps, a blogging program ....”)
} 
broad inclusion is necessary. ${ }^{167}$ Some scholars, however, have expressed concern in previous reporter's privilege debates that determining such delineation would prove difficult to accommodate the needs of both journalists and judicial officers. ${ }^{168}$ If Congress thus wishes to restrict the limit of protected individuals under a federal shield law, it would have to enact subsequent federal legislation to do so; otherwise, if left as written and adopted, the reporter's privilege extends to a wider range of individuals, a scenario which most journalism advocates would surely support. ${ }^{169}$ In either situation, a level of reporter's privilege is recognized by the federal government.

It is important to recall that the protections outlined in the IADPHR are qualified by the constraints established by the IACHR. The IACHR posits that freedom of expression, and specifically the freedom to maintain source confidentiality, can be curtailed in certain circumstances, such as those dealing with matters of national security. ${ }^{170}$ This pretty clearly aligns with ideals presented by Congress: the Free Flow of Information Act of 2013 certainly provided a broad set of criteria under which the federal government could compel a journalist to disclose his confidential source. ${ }^{171}$

Some of the critics advocating for a federal shield law would likely be discontent with the establishment of a qualified reporter's privilege, as ratification of the IADPHR would provide. In

\footnotetext{
167 See Davidson, supra note 8, at 1325. ("[P] technology calls for. Anyone with a computer and a little bit of knowledge about how to use it can disseminate his or her information instantaneously and globally!')

168 Anthony L. Fargo, The Year of Leaking Dangerously: Shadowy Sources, Jailed Journalists and the Uncertain Future of the Federal Journalist's Privilege, 14 WM. \& MARY BILL RTS. J. 1063, 1119 (2006) ("[T]here are dangers there, particularly in regard to defining who may claim protection. There is, in short, no perfect way to balance the needs of journalists and triers of fact.").

${ }^{169}$ State courts have already demonstrated a willingness to broadly interpret who is afforded shield law protections as a "journalist." See Fargo, Analyzing Federal Shield Law Proposals, supra note 82, at 58.

${ }^{170}$ See American Convention on Human Rights, supra note 102.

${ }^{171}$ Free Flow of Information Act, supra note 83.
} 
their 2012 article advocating for a federal shield law, Sandra Davidson and David Herrera argue that "[p]ierce-proof shield laws are . . important not only for journalists but also for this country. The United States, if it is to be a leader for press freedom in our complex world, must not dissemble by creating shield-law exceptions that inevitably create bias against reporters." 172 The authors again draw on the analogy of attorney-client privilege: "[t]he only shield that is truly worthy of the name is an absolute shield - a declaration that journalists will not be jailed for refusing to divulge the names of confidential sources ... a federal shield law should discard the case-by-case method of a qualified privilege and give journalists 'an absolute privilege' based on the attorney-client privilege." ${ }^{173}$ Indeed, even Justice Stewart expressed concern in his Branzburg dissent, noting that “[s]ooner or later, any test which provides less than blanket protection to beliefs and associations will be twisted and relaxed so as to provide virtually no protection at all."174

However, while absolute privilege presents obviously preferential rationale for some journalism advocates, one must take a pragmatic approach to the contemporary issues of federal adjudication. ${ }^{175}$ It is simply illogical to expect the United States judiciary to create a carte blanche reporter's privilege, particularly in matters of national security. One cannot expect a court to develop a privileged class of potential witnesses with different (and, one might argue, elevated) rights and privileges over another undistinguished witness. As one scholar noted, "[a]n absolute shield against disclosure of confidential sources to federal grand juries would create an 'institutional' privilege unique to the press, in contravention of Supreme Court and federal case

\footnotetext{
172 Davidson, supra note 8, at 1284.

${ }^{173}$ Id. at 1290 (citing Eric M. Freedman, Reconstructing Journalists' Privilege, 29 CARDOZO L. REV. 1381,1386 (2007)).

${ }^{174}$ Branzburg, 408 U.S. at 720 (Stewart, J., dissenting).

${ }^{175}$ Capocasale, supra note 63, at 363.
} 
law, the Fifth Amendment, sensible public policy concerns, and the Press Clause itself."176 Such privileges have not been afforded as absolute even in well-recognized institutional privileges, such as the attorney-client privilege, physician-patient privilege, or even concealment of identities of "confidential sources in the context of Congressional investigations and proceedings . . .."177

Yet the benefits of establishing a qualified privilege are twofold. First, it establishes baseline protections for journalists to maintain source and information confidentiality; unlike journalists' reliance on the provisions laid out in Branzburg, a qualified privilege at least provides journalists with knowledge of the thresholds that must be overcome to require disclosure. As Justice Powell argued in his Branzburg concurrence, "[t] he asserted claim to privilege should be judged on its facts by the striking of a proper balance between freedom of the press and the obligation of all citizens to give relevant testimony . . .."178

Second, having an established foundation on which further action can be taken allows for journalists, judges and legislators to assess the effectiveness of the policy and make appropriate changes as necessary. An "all or nothing" approach such as absolute privilege understandably presents concerns for legislators, ${ }^{179}$ since it would invite more scrutiny and public ire to whittle down a broad privilege than it would be to expand upon a more narrow privilege as deemed necessary by trial and error. Adopting the IADPHR as a template for establishing a qualified privilege would present such an opportunity, since the United States would not be precluded from

\footnotetext{
${ }^{176} I d$. at $382-83$.

${ }^{177} \mathrm{Id}$. at 365 .

${ }^{178}$ Branzburg, 408 U.S. at 710 (Powell, J., concurring).

${ }^{179}$ See Fargo, supra note 82, at 73 ("An absolute privilege would bring greater consistency to the law but is likely to be politically unpopular ... Courts in states with shield laws have not been shy about funding 'absolute' privileges to be less than absolute when they conflict with constitutional rights such as those protected by the Sixth Amendment, so the utility of an absolute privilege is questionable.").
} 
adding circumstances under which journalists could maintain confidential sources that the declaration does not consider.

In reality, relying on the Senate to ratify the IADPHR is at best unreasonably optimistic. Contemporary history has shown that the Senate repeatedly demonstrates a decided unwillingness to assign to the United States legal obligations that it has not itself created. ${ }^{180}$ Yet efforts to enact a federal shield law by more conventional means (meaning the bicameral legislative process) have failed to make any significant progress on a matter that individual states have been able to regulate. And while the ratification is an unlikely avenue to seeing a federal reporter's privilege enacted, it is still a legal means by which such protections could be enacted. As such, it is worth considering the adoption by ratification of an international agreement (specifically the IADPHR) laying out a framework that would establish protections envisioned by both scholars and legislators in a manner that comports with, and in some instances alleviates, concerns raised with other efforts to enact a federal shield law.

\section{CONCLUSION}

The United States is widely considered one of the bellwethers in providing fundamental protections for its citizens. That it does not afford for its journalists protections that its allies have deemed as fundamental rights should be, and indeed is, seen as a gross injustice by a nation that touts its freedom of the press. As Justice Stewart argued in his Branzburg dissent, "effective selfgovernment cannot succeed unless the people are immersed in a steady, robust, unimpeded, and

\footnotetext{
180 Joshua Keating, The U.S. Will Not Ratify Any Treaty Unless It Has To Do With Fish, SLATE.com (Aug. 28, 2014, 9:00AM),

http://www.slate.com/blogs/the_world_/2014/08/28/obama_s_new_international_climate_change_strategy_how_do _you_negotiate_treaties.html [perma.cc/77A4-FYBZ ](“The slew of other treaties that U.S. presidents have signed but the Senate has not ratified include measures to prevent enforced disappearance, torture, cluster munitions, and discrimination against women.").
} 
uncensored flow of opinion and reporting which are continuously subjected to critique, rebuttal, and re-examination." 181 Yet despite the vast majority of states offering protections to ensure that information gathered from confidential sources can be disseminated without threat of judicial action, the federal government has thus far been unable to enact similar legislation offering such protections to journalists from the threat of federal subpoena.

Ratifying the IADPHR, therefore, presents arguably the best and likely easiest, opportunity for the United States to enact a federal reporter's privilege. By its language, the IADPHR would extend to a wide range of individuals protections under which they could carry out the fundamental duty of investigative reporting under the definition of "social commentators." 182 By its creation and drafting history, the United States could easily establish threshold criteria under which the federal government could still receive information that is absolutely critical to its obligations. And by having some type of protection in place, Congress and journalists could begin the inevitably long but ultimately productive series of trial and error under which the federal reporter's privilege would be sufficiently clarified and settled. It is not a perfect proposal, but in order to make sure that stories, like those of James Risen and Judith Miller, do not continue to be commonplace, the United States must take initial steps to align itself with its international peers.

\footnotetext{
${ }^{181}$ Branzburg, 408 U.S. at 715 (Stewart, J., dissenting).
}

182 Background and Interpretation, supra note 108. 